\title{
TEORI TA‘AQQULÎ DAN TA‘ABBUDÎ MENURUT FIQH JINAYAH DAN APLIKASINYA DALAM PENERAPAN SANKSI PIDANA KORUPSI
}

\author{
Nasrullah \\ Fakultas Syariah STAIN Loksemawe Aceh \\ E-mail:nasrullah_arull@yahoo.com
}

\begin{abstract}
One of definitions of the corruption is the misuse of power, abuse of power, or the misuse of public position for personal gain. Corruption is part of "extraordinary crime", which is the act which destroys the economic, social, and the eradication should be done with the priority scale. The penalty or sanction against corruption actors should be done firmly, strongly, and emphatically that makes deterrent effect. In Islam, one of the approaches for the application of penalty in Islamic Criminal Law can be done theoretically with ta'abbudî and ta'aqqulî approach. Therefore, this paper will explain the theory of ta'aqqulî and ta'abbudî according to Islamic Criminal Law perspective and its application to the corruption actors.
\end{abstract}

\begin{abstract}
Abstrak
Salah satu definisi korupsi adalah tindakan penyalahgunaan kekuasaan (abuse of power) atau menyelahgunakan kedudukan publik untuk kepentingan pribadi. Korupsi merupakan bagian "extra ordinary crime", yaitu perbuatan yang menghancurkan hak ekonomi, sosial masyarakat, dan penumpasannya harus dilakukan dengan skala perioritas. Hukuman terhadap pelaku korupsi harus dilakukan dengan tegas yang membutnya jera. Dalam Islam, salah satu pendekatan dalam penerapan hukuman dalam Fiqih Jinayah dapat dilakukan dengan pendekatan teori ta'aqqulî dan ta'abbudî. Oleh karenanya, tulisan ini akan menjelaskan teori ta'aqqulî dan ta'abbudî menurut fiqh Jinayah dan aplikasinya dalam penerapan sanksi pidana korupsi.
\end{abstract}

Kata Kunci:

Korupsi, Ta'aqqulî, Ta'abbudî, Fiqh Jinayah

\section{A. Pendahuluan}

Korupsi mengacu pada berbagai aktivitas atau tindakan secara tersembunyi dan illegal untuk mendapatkan keuntungan demi kepentingan pribadi dan golongan. Namun dalam perkembangannya terdapat penekanan bahwa korupsi adalah tindakan penyalahgunaan kekuasaan (abuse of power) atau menyalahgunakan kedudukan publik untuk kepentingan pribadi. ${ }^{1}$ Atau seseorang secara

${ }^{1}$ Lebih lanjut dalam definisi tersebut mencakup prilaku pejabat-pejabat sektor publik, baik politisi maupun pegawai negeri, yang memperkaya diri mereka secara tidak pantas dan melanggar hukum, atau orangorang yang dekat dengan mereka, dengan menyalahgunakan kekuasaan yang dipercayakan pada mereka. Jeremy Pope, Strategi Memberantas Korupsi; Elemen Sistem Integrasi Nasional (Jakarta: Yayasan Obor Indonesia. 2003), hlm. 6-7. tidak halal meletakkan kepentingan pribadinya di atas kepentingan rakyat serta mengabaikan cita-cita sumpah yang dilayaninya. ${ }^{2}$ Praktek korupsi seperti ini masih tersebar di seluruh wilayah Indonesia dan menyebar di seluruh aspek kehidupan, baik di sektor penerimaan maupun pengeluaran Negara yang dilakukan secara sistematis.

Definisi mengenai korupsi banyak sekali, namun menurut hukum positif (Undangundang Nomor 31 Tahun 1999 jo Undangundang Nomor 20 Tahun 2001 tentang Pemberantasan Tindak Pidana Korupsi) adalah perbuatan setiap orang baik pemerintahan maupun swasta yang melanggar hukum me-

${ }^{2}$ Robert Klitgaard, Membasmi Korupsi (Jakarta: Yayasan Obor Indonesia. 2001), hlm. 19. 
lakukan perbuatan memperkaya diri sendiri atau orang lain atau korporasi yang dapat merugikan keuangan negara. Meskipun perbuatan korupsi adalah sesuatu yang tidak dikehendaki oleh masyarakat dan pelakunya dikenakan sanksi yang berat, namun tindak pidana korupsi kadangkala dilakukan dengan teknik yang sangat canggih dan sulit untuk dibuktikan melalui cara pembuktian biasa. Bahkan sulit untuk dideteksi adanya unsur kolusi dan nepotisme, sehingga korupsi terus muncul dalam banyak bentuk dan membentang dari soal kecil sampai soal yang besar, baik di sektor swasta maupun sektor pemerintah, atau sekaligus kedua-duanya. ${ }^{3}$

Tindak pidana korupsi saat ini demikian menonjol dan terjadi sampai pada semua jajaran dan ini dapat dikategorikan sebagai "extra ordinary crime", yaitu perbuatan yang menghancurkan hak ekonomi, sosial masyarakat, dan penumpasannya harus dilakukan dengan skala perioritas. ${ }^{4}$ Secara hukum, praktik korupsi adalah cermin tingkat kesadaran hukum suatu warga negara. Korupsi seperti halnya di Indonesia adalah bentuk tindak pidana, dan maraknya korupsi dapat berarti rendahnya kesadaran hukum dan hancurnya supremasi hukum. Oleh karena itu, tulisan ini akan menjelaskan teori ta'aqqulî dan ta'abbudî menurut figh Jinayah dan aplikasinya dalam penerapan sanksi pidana korupsi.

\section{B. Prinsip Ta'aqulî dan Ta'abudî}

Dalam perspektif kajian fiqh Jinayah, teori ta'aqqulî dan ta'abbudî dapat dijadikan acuan dalam rangka mengaplikasikan dan atau penerapan sanksi pidana. Kedua teori ini saling bersinergi (antara nash dan akalpikiran) dalam menentukan dan mengaplikasikan suatu sanksi yang tidak dapat diperdebatkan, kecuali menyangkut persoalan

\footnotetext{
${ }^{3}$ Robert Klitgaard, Membasmi Korupsi. hlm. 19-20.

${ }^{4} \mathrm{Hal}$ di atas dapat diperhatikan sejak Kongres PBB VII yang diadakan di Kota Milan-Italia Tahun 1986 tentang Crime Prevention and Criminal Justice in The Context of Development and a New International Economic Order. Dari Kongres itu berkembang dan diakui bahwa adanya suatu pergeseran paradigma terhadap kejahatan, seperti korupsi. Atmasasmita R, Sekitar Masalah Korupsi, Aspek Nasional dan Aspek Internasional (Bandung: Maju Mundur. 2004), hlm. 40.
}

yang syubhat. Namun dalam ranah fiqh Jinayah, tindak pidana korupsi tidak dibahas secara khusus.

Ta'aqqulî secara maknawi adalah menunjukkan kepada hal yang masuk akal, rasional, dapat dipikirkan, atau dipahami. Sedangkan menurut istilahi, ta'aqqulî adalah suatu upaya penalaran terhadap maksud ayat dalam rangka memahami makna yang tersirat dari bentuk-bentuk perintah dan larangan yang tersurat. ${ }^{5}$ Ta'aqqulî ini bersifat duniawi dan maknanya dapat dipahami melalui nalar/akal (ma'qulat al-ma'nâ) atau rasional. Manusia dapat melakukannya dengan bantuan nalar dan pemikirannya terhadap maksud dan pemahaman yang tersirat dari bentuk tersurat itu.

Apabila merujuk kepada pengertian tersebut, maka ta'aqqulî adalah sesuatu (perintah atau larangan) dimana dalam nash mengandung 'illat hukum atau hikmahnya. Untuk membedakan antara 'illat dan hikmah, maka dapat dikemukakan definisi 'illat dan hikmah. Wahbah al-Zuhaylî menyatakan:

$$
\begin{aligned}
& \text { وأما الحكمة فهي المصلحة التى يراد بالحكمة تحققها } \\
& \text { والمفسدة التى يراد دفعها. والحكمة لا تصلح معرفة للحكم } \\
& \text { الشرعي فن كل حال من الأحوال لأها وصف ظاهر غير } \\
& \text { منضبطو يختلف باختلف البينات وأنظار الناس. وأما العلة } \\
& \text { فهى وصف ظاهر منضبط معرف للحكى . }
\end{aligned}
$$

Adapun hikmah adalah maslahat yang dikehendaki realisasinya oleh hukum atau mafsadat yang dikehendaki tertolaknya. Hikmah tidak dapat menjadi mu'arrif (ciri pengenal) hukum syara' dalam segala situasi karena ia adalah suatu sifat yang dhâhir (jelas) yang tidak mundhabit (tidak tetap) yang berbedabeda menurut lingkungan dan pandangan manusia. Sedangkan 'illat adalah suatu sifat yang jelas dan mundabit (tetap) yang menjadi mu'arrif (ciri pengenal) hukum syara'. ${ }^{6}$

Dalam sejarah hukum Islam (periodelisasi figh) bahwa setelah masa Nabi Muham-

${ }^{5}$ Abuddin Nata, Al-Quran dan Al-hadîth (Jakarta : Raja Grafindo Persada. 1994), hlm. 142.

${ }^{6}$ Wahbah al-Zuhaylî, Ushûl al-Figh. hlm. 96. 
mad saw.,' teori ta'aqqulî muncul dan berkembang pada masa kekhalifahan 'Umar bin Khathâb yang memahami ajaran/ hukum Islam dengan pendekatan ilmiah rasional (ta'aqqulî) berlandaskan maqâshid alsyarî'ah, dimana dapat menyentuh 'illat dan hikmah tasyri' serta dapat dicerna oleh penalaran umat Islam terutama dalam masalah kemasyarakatan. Hal ini terlihat dari ketentuan-ketentuan hukum Islam berdasarkan ijtihad atau pikiran yang brilian 'Umar sendiri dalam penetapan hukumnya, seperti tidak membagikan harta $f a^{\prime} i$ (harta yang didapat dalam peperangan, tidak memotong tangan pencuri, tidak memberikan zakat kepada golongan muallaf, dan sebagainya. ${ }^{8}$

Memang secara tekstual (bayâni) contoh-contoh fiqih tersebut kelihatannya bertentangan dengan tasyri“ Ilâhi, akan tetapi dari segi pengembangan hukum Islam dan meninggalkan kejumudan, 'Umar telah meletakkan pondasi penalaran ushûl fiqih (tasyri" wad'i) bahwa hukum Islam tidak kaku, rigid dan mengikuti perkembangan zaman yang

\footnotetext{
${ }^{7}$ Setelah Nabi SAW. wafat, para shahabat belakangan banyak memberi penafsiran metode ijtihâd, sekalipun cenderung memproyeksikannya kepada konsepkonsep yang berkembang pada periode kematangan pemikiran hukum Islam. Ada ijtihad para shahabat semuanya terhimpun ke dalam konsep al-qiyash. Muhammad al-Khuḍarî Bayk, Ushûl al-Figh (Cairo: Dâr al-Fikr al'Arabî. 1988), hlm. 115. Ada juga sebagian shahabat berijtihad dalam batas-batas pemahaman al-Quran dan Sunnah, sedang sebagian lain menggunakan al-qiyash dan al-mashlahah. Muhammad Abû Zahrah, Târîkh alMadlâhib al-Islâmiyyah (Mesir: Dâr al-Fikr al-‘Arabî. t.th.), Juz II, hlm. 23. Selain itu ada juga ijtihad para shahabat itu tersimpul dalam tiga bentuk, yaitu; menafsirkan nash-nash; menggunakan metode alqiyâsh; dan menggunakan mashlahah mursalah dan istiḩân. Muhammad Salâm Madkûr, Al-Madkhal li alFigh al-Islâmî (Bairût: Dâr al-Fikr. t.th.), hlm. 22. Terlepas dari apa pun interpretasi tentang bentuknya, kreasi ijtihad mereka disebabkan kuantitas nash hukum terbatas, sedangkan kasus hukum yang muncul tidak terbatas. Oleh karena itu, sesuatu yang tidak terbatas tidak akan tercakup oleh yang terbatas. Muhammad Abû Bakar al-Syahrastânî, Al-Milal wa al-nihâl (Bairût: Dâr al-Fikr. t.th.), hlm. 202.

${ }^{8}$ Menyangkut contoh-contoh tersebut baik dalam konteks penerapan nash-nash khusus maupun masalah-masalah yang tidak ada nash khusus lebih lanjut dapat diperhatikan dalam Muhammad Baltaji, Metodologi ljtihad Umar bin Khathab, Penerj. Masturi Irham, Judul Asli: Manhaj 'Umar bin al-Khaththâb fi al-Tasyrî' Dirâsah Mastaw'abah li Fiqhi 'Umar wa Tanzîmâtuh (Jakarta: Khalifa. 2005), hlm. 177-210 dan 260.
}

sesuai dengan kemaslahatannya. Karena itu, hukum Islam pada dasarnya ditentukan dan diterapkan sesuai 'illat dan hikmah tasyri' yang bermuara pada pencapaian kemaslahatan bagi umat.

Selain pemahaman hukum melalui wahyu dan sabda Nabi saw. (bayâni/ tekstual), 'Umar bin al-Khathâb telah melakukan suatu terobosan terhadap pemahaman hukum Islam sehingga melahirkan model penalaran istishlahî, yaitu penalaran hukum Islam yang bertumpu pada suatu pencapaian kemaslahatan. Sedangkan unsur kemafsadatan dalam suatu hukum, maka melalui penalaran istislahi harus disingkirkan dan dihilangkan dengan mengedepankan unsur mashlahat. Artinya bahwa suatu hukum tetap mengandung unsur mashlahat dan mafsadat, namun perioritasnya mashlahat lebih diutamakan untuk kepentingan individu dan kolektif.

Setelah berkembangnya model penalaran hukum Islam yang dilakukan 'Umar bin Khathâb, pada masa berikutnya para fuqahâ (terutama dikalangan Imâm mazhab) memandang bahwa pada masalah-masalah selain ibadah. Karena tidak begitu mengalami tantangan di zaman yang semakin bertambah modern. Namun nash-nash (al-Quran dan al-Hadits) khususnya yang menyangkut bidang mu'âmalat atau adat pada umumnya disebutkan atau diisyaratkan hikmah atau 'illat hukumnya.

Masalah-masalah kemasyarakatan semakin hari semakin banyak yang muncul dan membutuhkan jawaban dari sudut hukum Islam yang menurut pendapat penulis dapat dijawab melalui pendekatan ta'aqqulî (nalar/pikiran) terhadap nash-nash (al-Quran dan al-Hadits). Hal inilah yang membuka peluang bagi para mujtahid untuk melakukan pengembangan terhadap hukum Islam melalui berbagai metode, misalnya, qiyâsh, istihsan, istishab, mashlahah mursalah dan sebagainya.

Selain itu, perkataan (teori) ta'abbudî terambil dari kata dasar 'abada (عبد) yang berarti menyembah, patuh dan taat kepada Allah swt.9 'Abdul Hamîd Al-Syarwanî, me-

\footnotetext{
${ }^{9} \mathrm{~A} h m a d$ Warson Munawwir, Kamus al-Munawwir (Yogyakarta: Yayasan Al-Munawwir. 1984), hlm. 951.
} 
ngutip pendapat beberapa fuqaha menyatakan:

$$
\begin{aligned}
& \text {... بان التعبدي هو الذي لم يدرك له معنى وقديجاب عن } \\
& \text { الشارح بأغم قد يطلقون التعبدي على ما لم يظهرله علة } \\
& \text { موجبة للحكم وان ظهرله حكمة }
\end{aligned}
$$

Al-Ta'abbudî adalah sesuatu (perintah/larangan dalam nash) yang tidak diketahui ma'na (dibaliknya) dan ada pula yang menerangkan kepada saya (al-syarîh) bahwa para fuqaha memaksudkan al-ta'abbudî itu adalah sesuatu yang tidak tampak jelas 'illat yang menyebabkan adanya hukum sekalipun ada hikmah yang tampak. ${ }^{10}$

Dengan kata lain, ta'abbudî adalah ketentuan-ketentuan hukum dari nash (alQuran dan al-Hadits) yang harus diterima oleh manusia apa adanya dan dilaksanakan sesuai dengan ketentuan hukum tersebut, tanpa ditawar-tawar, serta tanpa memerlukan penalaran karena ketentuan itu bersifat absolut. Manusia hanya melaksanakan sesuai dengan ketentuan nash, tidak boleh mengubah, mengurangi atau menambahnya. ${ }^{11} \mathrm{Hal}-$ hal yang telah diatur menurut ketentuan nash yang qath'i dipandang oleh para fuqahâ' sebagai masalah ta'abbudî الأمور التعبديه ) yang mesti ditaati dan dijalankan oleh umat Islam tanpa perlu bertanya mengapa dan bagaimana. Meskipun sebenarnya (secara filosofis dan dalam beberapa kasus tertentu) bisa dipahami dengan pendekatan ta'aqqulî, seperti dalam masalah tayammum, membersihkan najis dengan tanah dan semacamnya.

Contoh lain tentang jumlah raka'at dalam shalat lima waktu yang tidak boleh diubah, ketentuan bertayammum dengan debu, kewajiban berpuasa di bulan Ramadhan, ketentuan zakat, dan pelaksanaan Ibadah haji. Kesemuanya itu harus diikuti secara apa adanya sesuai petunjuk syarî̀ dalam nash dan akal sama sekali tidak dapat mengetahui 'illat hukumnya, kenapa demi-

\footnotetext{
10،Abdul Hamîd Al-Syarwanî, Hawasyi al-Syarwanî (Bairût: Dâr al-Fikr. t.th.), juz IV, hlm. 272.

${ }^{11} \mathrm{LM}$. Abdul Mujib (ed.), Kamus Istilah Fiqih (Jakarta : Pustaka Firdaus. 1994), hlm. 352.
}

kian serta apa makna dibalik ketentuan-ketentuan tersebut.

Dengan pendekatan ta'abbudî, hukum Islam dapat diterima apa adanya tanpa ada komentar. Pendekatan ini banyak digunakan pada periode awal, yaitu masa Nabi saw. dalam menganalisis hukum Islam dan periode sahabat (kekahlifahan Abû Bakar alshidiq) yang masih murni menjalankan aturan-aturan sebagaimana ketentuan yang ada pada periodelisasi Nabi saw., meskipun pada masa Abû Bakar banyak terdapat persoalan $^{12}$, namun landasan pengacuannya adalah pada pewahyuan dan sabda Nabi saw. Pendekatan ini cenderung menjadikan pikiran kaum muslimin menjadi jumud, karena kausalitas 'illat dan hikmah tasyrî' tidak banyak terungkap, karena mengikuti dan mengamalkan sesuai aturan yang ada.

Pada prinsipnya ruang lingkup hukum Islam mencakup dua hal, yaitu hubungan manusia dengan Tuhan yang disebut dengan Ibadah (wilayah ta'abbudî), dan hubungan antara sesama manusia dan lingkungannya yang disebut dengan mu'âmalah (wilayah Ta'aqqulî). ${ }^{13}$ Kedua bidang tersebut (ibadah dan mu'amalah), Ibn Taymiyyah menjelaskan bahwa ibadah adalah menyangkut kemaslahatan agama, sedangkan mu'âmalah atau 'adat adalah menyangkut kebutuhan duniawi manusia. Dari itu, yang menjadi prinsip dalam hal Ibadat ialah adanya perintah dari Allah yang menurunkan agama dalam bentuk syarî́at, tanpa adanya perintah Allah yang tertuang dalam syarî'at-Nya, ibadah tidak boleh dilakukan. Kemudian pada ibadah itu

\footnotetext{
${ }^{12}$ Masa kekahlifahan Abû Bakar al-SHiddîq hanya sebentar dan disibukkan oleh hal-hal yang bersifat intern seperti memerangi orang-orang yang murtad. Berbeda dengan dengan masa kekhalifahan 'Umar bin Khaththab yang agak lama dibanding dengan masa Abû Bakr, di samping stabilitas keadaan saat kekhalifahan 'Umar tidak seperti Abû Bakar, didukung pula dengan luasnya kekuasaan Islam dan kerapian administrasi negara. Oleh karena itu, wajar saja bahwa masa kekhalifahan 'Umar bin Khathab hukum-hukum Islam lahir dari seorang pribadi disertai keadaan yang mendukung itu. Hal ini menjadi suatu perbandingan dan kajian bagi generasi berikutnya, sehingga melahirkan kajian yang sangat monumental dan mengesankan.

${ }^{13}$ Wahidin, Metodologi Pemikiran ljtihad Fiqih Antara Pendekatan Ta'abbudî dan Ta'aqqulî, Jurnal Hukum Islam, vol. V No. 3. Juli 2006, hlm. 251.
} 
adalah tawqifî (berdiam diri tanpa melakukan sesuatu) hingga ada aturan Allah yang memerintahkannya. Sedangkan prinsip dalam hal mu'âmalat ialah kebiasaan manusia dalam mengurus kebutuhan-kebutuhan hidup duniawinya; yang menjadi prinsip dalam hal ini adalah kebolehan atas segala sesuatu selama tidak ada larangan dari Allah, dan pada mu'âmalat itu adalah al-'afwu (keman'afan, kebolehan) segala sesuatu hingga ada larangan dari Allah. Syarî́at yang diturunkan menyangkut mu'âmalat adalah untuk mengajarkan etika kehidupan. Dari itu, manusia tidak dapat menciptakan suatu bentuk ibadah tanpa adanya perintah Allah dan manusia tidak dapat melarang sesuatu tanpa ada larangan Allah. ${ }^{14}$

Hukum yang menyangkut ibadah sebagian besar diatur dengan nash-nash yang qath'i, baik dalam al-Quran maupun Hadits, karena tidak menyentuh kepentingan lahirlah manusia dan bersifat ghayr ma'qul alma'na, tidak mampu dijangkau akal pikiran manusia. Oleh karena itu harus diterima apa adanya sebagaimana ditentukan oleh nas. Dengan demikian, manusia tidak dapat menentukan bentuk ibadah lain selain yang telah ditentukan oleh nash. Rasulullah saw. dalam suatu Hadits riwayat 'Âisyah bersabda:

$$
\text { من عمل عملا ليس عليه أمرنا فهو رد. (رواه مسلم) }
$$

Barangsiapa melaksanakan suatu amal yang bukan atas perintah Kami, maka ia ditolak. (HR. Muslim) $^{15}$

Berdasar Hadits di atas, para ulama fiqh merumuskan suatu kaidah fiqh:

$$
\text { الأصل في العبادة البطلان حتى يقوم دليل على الأمر. }
$$

Yang menjadi (pegangan) pokok dalam ibadah adalah batal (tidak boleh dilakukan), sehingga ada dalil yang memerintahkannya. 16

\footnotetext{
${ }^{14}$ Ibn Taimiyyah, Kitab Iqâmah al-Dalîl 'alâ Ibthâl alTahlîl dalam Majmu'ah Fatawa Ibn Taimiyyah (Bairût : Dâr al-Fikr. 1980), juz III, hlm. 272-273.

${ }^{15}$ Shahîh Muslim, No. 4590, juz V, hlm. 132.

${ }^{16}$ Abdul Hamid Hakim, Al-Bayân (Bukittinggi: Maktabah al-Ma'arif. 1939), hlm. 215.
}

Bertolak dari dasar tersebut, hukum dalam bidang ibadah bersifat ta'abbudî, manusia tidak diberi wewenang untuk mengembangkan atau memperbaharuinya. Segala bentuk ibadah yang baru dan menyimpang dari ketentuan Allah disebut bid'ah. Berlainan dengan nash-nash dalam masalah ibadah, nash-nash dalam bidang mu'âmalat sebagian besar adalah nash yang zhannî, ${ }^{17}$ yang mengandung prinsip-prinsip umum tentang hubungan manusia dengan sesamanya. Sebagai dasar pegangan dalam bidang ini ialah firman Allah:

$$
\text { هو الذي خلق لكم مافى الأرض جميعا .... }
$$

Dia (Allah) telah menjadikan bagimu apa yang ada di muka bumi seluruhnya ...". (QS. Al-Baqarah: 2)

Dalam Hadits riwayat Aisyah Nabi saw. menegaskan:

$$
\text { ... أنتم أعلم بأمور دنياكم. (زواه مسلم) }
$$

...Kamu lebih mengetahui urusan duniamu. (HR. Muslim) $)^{18}$

Dari ayat dan Hadits tersebut para fuqaha menyimpulkan suatu kaidah:

$$
\text { الأصل فن العقود والمعاملات الصحة حتى يقوم دليل على }
$$

Yang menjadi (pegangan) pokok dalam transaksi dan mu'âmalat adalah keabsahan, sehingga ditemukan dalil yang membatalkan dan mengharamkan. ${ }^{19}$

\footnotetext{
${ }^{17}$ Adanya pembedaan antara ta'aqqulî dan ta'abbudî dalam nash merupakan hasil istiqra' (penelitian mendalam) para ulama ushuliyyûn dimana pembahasan mengenai pendekatan Ta'aqquiî dalam mengembangkan ayat-ayat al-Quranyang ma'qul al-ma'na banyak terdapat di dalam bab Qiyash. Dari hasil istiqra' para ulama tersebut terdapat kaidah atau rambu-rambu untuk mengidentifikasi hal-hal mana yang bisa diaplikasikan qiyash dan mana yang tidak, karena untuk mencari 'illat dari suatu nash merupakan pekerjaan yang cukup sulit dilakukan. Dari sini dapat melihat urgensi ta'aqquî̀ dalam mengembangkan ayat-ayat ahkâm al-Quran dan juga ḥadîth terutama sekali metode qiyash sebagai alat ijtihad dalam menetapkan hukum sebagaimana dikatakan oleh Imâm al-Syâfi'î.

${ }^{18}$ SHahîh Mus Musim, No. 6277, juz VII, hlm. 95.

${ }^{19}$ Abdul Hamid Hakim, Al-Bayan. hlm. 215.
} 
Oleh karena nash-nash dalam bidang mu'âmalat sebagian besar berupa nash-nash yang zhannî dan berupa prinsip-prinsip umum, maka disini terdapat peluang bagi manusia untuk melakukan ijtihad, karena memang kandungan bidang mu'âmalat merupakan sesuatu yang dapat dijangkau dan dianalisis oleh pikiran manusia (ma'qul alma'na, Ta'aqqulî). Disamping itu, al-Syâthibi mengemukakan bahwa dalam kaitannya dengan mukallaf (orang yang dibebani hukum) secara garis besar membedakan materi fiqh menjadi dua bagian, yaitu; materi figh yang menyangkut ibadah; dan materi figh yang menyangkut 'adat (mu'âmalat). Secara filosofis ia telah merumuskan kaidah sebagai berikut:

$$
\begin{aligned}
& \text { الأصل في العبادة بالنسبة الى المكلف التعبد دون الالتفات } \\
& \text { الى المعاني وأصل العادات الالتفات الى المعاني. }
\end{aligned}
$$

Pada umumnya dalam hal ibadah yang menyangkut Mukallaf adalah al-Ta'abbud dengan tanpa berpaling kepada al-ma'ani,

\footnotetext{
${ }^{20} \mathrm{Al}$-Syâthibî, Al-Muwâqât, hlm. 300. Takalif dalam pandangan al-Syâthibî juga bisa dipandang sebagai hak-hak Tuhan. Dalam pengertian ini mereka menjadi ta'abbudî. Akan tetapi al-Syâthibî memandang ta'abbudî sebagai pengertian umum hak-hak Tuhan. la membagi hak-hak tersebut menjadi tiga kategori; Pertama adalah hak-hak yang semata-mata milik Tuhan saja, semisal Ibadat; Kedua, hak-hak Tuhan yang juga melibatkan hak-hak manusia, tetapi pertimbangan hakhak Tuhan lebih dominan; dan Ketiga, hak-hak Tuhan di mana pertimbangan hak-hak manusia lebih dominan. Kategori yang ketiga inilah mashlahah atau ma'na tercakup secara langsung. Lebih lanjut ia mengatakan bahwa hak-hak Tuhan berarti situasi di mana dipahami dari syara' (hukum) bahwa si mukallaf tidak punya pilihan (khiyarah), apakah ma'na itu bisa dipahami ataukah tidak. Hak manusia didefinisikan sebagai apa yang merujuk kepada mashâlih manusia di dunia ini, sedangkan mashâlih di akhirat pada umumnya merupakan hak-hak Tuhan. Mengingat definisi-definisi ini, al-Syâthibî menyimpulkan bahwa Ibadat pada dasarnya merujuk kepada hak-hak Tuhan, dan 'adat merujuk kepada hak-hak manusia. Ibid. hlm 318-320. Dengan demikian, dalam bidang Mu'amalat ('adat) terdapat peluang bagi manusia untuk melakukan pembaruan, dan memang sudah menjadi kebutuhan manusia, sesuai dengan sifat sosial yang tidak terlepas dari perubahan. Di sinilah terdapat urgensi ta'aqquî́ dalam pengembangan hukum Islam dengan berijtihad meneliti dan menelusuri 'illat-'illat hukum dalam ayatayat aḥkâm al-Quran yang mana metode-metodenya telah dirumuskan oleh para ulama ushuliyyûn.
}

sedangkan pada umumnya dalam adat adalah menoleh kepada al-ma'âni.

Kesimpulan ini lebih ditunjukkan oleh argumen; Pertama, dari penyelidikan tentang syarî́at dapat diketahui secara induktif bahwa ketetapan-ketetapan semisal thaharah dan tayammum di bidang ibadah adalah sulit dijelaskan, kecuali dalam term-term Ta'abbud. Di lapangan 'adat jelas bahwa ketetapan-ketetapan syarî́at didasarkan pada mashlahah manusia. Dengan demikian secara induktif diketahui bahwa dalam 'adat, sang Pembuat Hukum (al-Syâri') mengandalkan pada pertimbangan mashlahah. Kedua, dalam ibadah perluasan lingkup Ta'abbud tidaklah dikehendaki. Dengan perkataan lain, kewajiban dibatasi pada perintah-perintah spesifik yang tercakup dalam ibadah. Itulah sebabnya mengapa tidak ada alasan eksplisit yang diberikan untuk mengeluarkan perintah-perintah itu. Sebaliknya, dalam kasus 'adat, perluasan aturan-aturan merupakan tujuan. Karenanya al-Syâri' dengan penuh kemurahan menjelaskan aturan-aturan hukum yang berkaitan dengan 'adat berkenaan dengan 'illat dan hikmah-hikmahnya.

\section{Penerapan Ta'aqqulî dan Ta'abbudî}

Mengenai aplikasi dalam penerapan sanksi terhadap kasus-kasus tindak pidana korupsi, teori ta'aqqulî dan ta'abbudî dalam figh jinâyat (hukum pidana Islam) merupakan dua teori berkenaan dengan pemahaman kontekstualisasi dan tekstualisasi. Dua pemahaman ini dalam realitasnya sangat berbeda dalam metode penalarannya sehingga menimbulkan pemahaman yang kontradiksi. Misalnya penerapan sanksi kepada korupsi, berdasarkan teori ta'aqqulî dapat diterapkan dan memang secara logika setiap yang melakukan kejahatan harus dihukum. Penerapan sanksi seperti itu tidak disebutkan secara spesifik dalam teori ta'abbudî. Meskipun demikian, metode penalaran secara kontekstual ( $T a^{\prime}$ aqquiî) pada dasarnya tidak terlepas dari acuan atau ketentuan nash yang menghendaki adanya upaya pencapaian tujuan penerapan hukum itu sendiri.

Selain dua teori ta'aqqulî dan ta'abbudî, berdasarkan literatur fiqh jinâyat (hukum 
pidana Islam) terdapat dua teori lain yang lebih spesifik menyangkut aplikasi dalam penerapan sanksi pidana korupsi, yaitu teori jawâjir dan zawâbir. Teori jawâjir adalah pidana ditujukan untuk tujuan pencegahan, baik umum maupun khusus, sedangkan dalam teori zawâbir adalah pidana ditujukan untuk pembalasan. ${ }^{21}$ Kedua istilah ini muncul ketika ulama figh membahas sifat hukum dalam berbagai tindak pidana tentang apakah bersifat preventif (pencegahan) atau paksaan (balas dendam) dan apabila hukuman telah dilaksanakan di dunia, apakah mereka masih disiksa di akhirat atau terbebas. Teori jawâjir dan zawâbir ini bila dikaitkan dengan hukum pidana umum, maka dapat disepadankan dengan retributif dan utilitarian yang dikenal dalam teori pemidanaan yang dikembangkan dalam hukum pidana. ${ }^{22}$

Antara teori jawâjir dan zawâbir terdapat perbedaan, seperti dikemukakan imâm 'Izz al-Dîn bin 'Abd al-Salam (577 H/1181 M 666 H/1261 M) ahli fiqh mazhab Syâfi'î yang dikutip oleh Juhaya, yaitu:

a. Zawâbir disyari'atkan sebagai pencegahan terhadap tindak pidana yang akan terjadi, sedangkan jawâjir disyari'atkan untuk mencapai kemaslahatan;

b. Zawâbir ditetapkan untuk perbuatan yang melanggar ketentuan Allah swt. sehingga dengan menghukum pelanggarnya orang lain akan mendapat pelajaran dan berusaha untuk menghindari perbuatan itu. Adapun jawâjir umumnya dikenakan pada seluruh pelaku pidana tanpa pandang bulu;

c. Jawâjir berkaitan dengan tindak pidana terhadap jiwa anggota badan, manfaat dari anggota badan, ibadah, harta dan manfaat. Adapun zawâbir berkaitan dengan pelanggaran Jinayah dan sikapsikap yang bertentangan dengan kehendak syara' seperti pembunuhan, zina, pencurian, perampok, pemberontakan, menuduh orang lain berbuata zina

\footnotetext{
${ }^{21}$ Juhaya S. Praja, Teori-Teori Hukum: Suatu Telaah Perbandingan dengan Pendekatan Filsafat (Bandung: Pascasarjana Universitas Islam Negeri. 2009), hlm. 111.

${ }^{22}$ Taqwaddin, Esensi Hukum Rajam (Lhokseumawe: Serambi. 2009), hlm. 24.
}

(qadhf), mengambil harta orang lain tanpa izin (gashab) dan minum minuman keras;

d. Zawâbir berkaitan dengan tindak pidana hudûd dan ta'zîr yang hukumannya dilaksanakan oleh hakim. Sedangkan jawâjir ditujukan terhadap tindak pidana yang pelaksanaan hukumannya diserahkan kepada orang yang dirugikan;

e. Jawâjir dalam masalah manfaat seperti seseorang yang menempati rumah orang lain tanpa izin dikenakan tanpa izin ganti rugi biaya, selama rumah itu ditempatinya. Contoh lain adalah untuk jiwa anggota badan dan manfaat anggota badan ialah denda (diyât) atau kafarah. Adapun hukuman terhadap pembunuhan yaitu qishas termasuk kedalam zawâbir. ${ }^{23}$

Perbedaan teori jawâjir dan zawâbir tersebut, apabila diperhatikan bentuk-bentuk hukuman yang ditentukan Allah dan Rasul-Nya bagi pelanggar pidana hudûd kelihatan bahwa hukuman yang harus diterima terpidana lebih berat dibanding tindak pidana itu sendiri. Tujuan utama penentuan hukuman adalah sebagai tindakan preventif dan bagi orang lain ia tidak melakukan tindak pidana yang sama setelah melihat pelaksanaan hukuman terhadap terpidana qishas dilaksanakan ditempat kalayak ramai sehingga dapat dijadikan pelajaran oleh masyarakat dan oleh mereka. Sesuai firman Allah swt.:

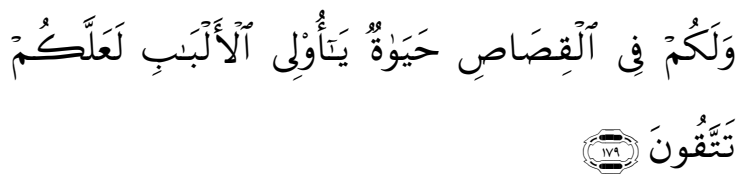

Dan dalam qishas itu ada (jaminan kelangsungan) hidup bagimu, Hai orang-orang yang berakal, supaya kamu bertakwa. (QS. AlBaqarah: 179)

Ulama mazhab Hanafi berpendapat bahwa tindak pidana hudûd dan ta'zîr disyari'atkan semata-mata sebagai tindak pencegahan bagi masyarakat di dunia. Sedangkan dosa terpidana tidak hilang kecuali melalui taubat. Alasan Jumhur ulama adalah huku-

\footnotetext{
${ }^{23}$ Juhaya S. Praja, Teori-Teori Hukum. hlm. 112-113.
} 
man yang telah ditentukan itu disamping sebagai tindak preventif di dunia, juga bisa menghapuskan hukuman di akhirat apabila telah dilaksanakan di dunia. Alasan lain yang dikemukakan Jumhur ulama adalah sabda Nabi saw. di depan para sahabat, yang berbunyi:

$$
\begin{aligned}
& \text { بايعوني على أن لا تشركوا بالله شيئا ولا تسرقوا ولا تزنوا ولا }
\end{aligned}
$$

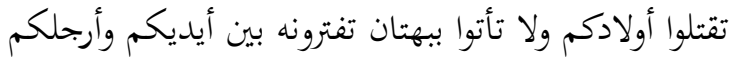

$$
\begin{aligned}
& \text { ولا تعصوا في معروف فمن وفى منكم فأجره على الله ومن }
\end{aligned}
$$

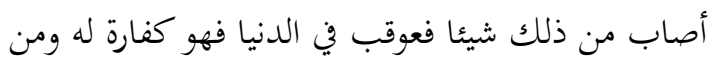

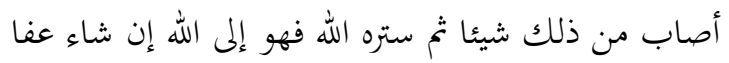

$$
\begin{aligned}
& \text { عنه وإن شاء عاقبه. } 24
\end{aligned}
$$

Berjanjilah kamu untuk tidak menyekutukan Allah, berzina, mencuri dan membunuh jiwa yang telah diharamkan Allah, kecuali disebabkan suatu alasan yang benar. Siapa yang berpegang teguh dengan janji ini Allah akan memberikan ganjaran. Dan siapa yang melanggar janji ini dengan melakukan salah satu perbuatan di atas lalu ia dikenai hukuman di dunia, maka hukuman itu menjadi kafarah (penghapus dosa) yang dilakukannya. Siap yang melakukan perbuatan itu secara diamdiam tidak terungkap sehingga tidak dapat dilaksanakan hukuman di dunia, maka persoalan dikembalikan kepada Allah jika dikehendaki-Nya, ia maafkan dan jika tidak dikehendakinya ia siksa. (HR. Bukhârî dan Muslim)

Hadits di atas dalam pandangan Jumhur ulama merupakan aspek jawâjir di akhirat tidak ada lagi karena hukuman di dunia sebagai zawâbir telah dilaksanakan. Oleh karena itu, penjelasan dua teori tersebut, dalam pandangan penulis sangat relevan menerapkannnya bagi tindak pidana korupsi, karena antara teori jawâjir dan zawâbir saling berkaitan, yaitu berbentuk pencegahan dan bilamana melakukannya, maka diberikan pembalasan dengan hukuman yang ditentukan, yaitu mulai hukuman minimum sampai hukuman maksimum.

\footnotetext{
${ }^{24}$ Shahîh Bukhârî, No. 18, juz I, hlm. 18. SHahîḥ̂ Muslim, No. 4558, juz V, hlm. 126.
}

\section{Kelayakan Konsep Hukum Materil dan Formal Islam bagi Pencegahan dan Pemberantasan Korupsi Melalui Peratu- ran Perundangan Indonesia}

Meskipun dalam khazanah pemikiran hukum Islam (figh) klasik, perilaku korupsi belum memperoleh porsi pembahasan yang memadai. Namun apabila mengistibațkan hukum, menurut disiplin ilmu fiqh terlebih dahulu dibahas hakikat masalah baik definisi, hukum, rukun dan syarat serta jenis-jenisnya, selanjutnya adalah hikmah pensyari'atan atau pelarangannya. Dalam konsepsi hukum Islam sangat sulit mengkategorikan tindak pidana korupsi sebagai delik pencurian (sirqah), karena beragamnya praktek korupsi itu sendiri yang umumnya tidak sesuai dengan definisi mencuri (ketentuan hukumnya adalah had potong tangan), yaitu seseorang mengambil harta yang bukan miliknya secara sembunyi-sembunyi dari suatu tempat. Tetapi jika mengambil sesuatu yang dipercaya padanya adalah pengkhianatan (khiyânah). ${ }^{25}$

Berbedanya mengkategorikan tindak pidana korupsi sebagai suatu kejahatan, hukum Islam mengenal dan membuka ruang untuk dipahami istilah-istilah lain sebagai tindak kriminal (ma'siat) yang mempunyai konotasi tersendiri sebagai unsur tindak pidana korupsi, seperti suap (risywah), penggelapan (ghulûl), penipuan (al-ghasysy), perampasan (gashab) dan sebagainya. Jenisjenis tindak kriminal ini, Islam sangat melarang melakukannya karena hal tersebut dapat merusak sendi-sendi akhlak, moral dan etika. Ketika para fuqahâ berbicara tentang kejahatan memakan harta benda manusia secara tidak benar (akl amwâl al-nâs bi albâthil) seperti yang diharamkan dalam alQuran, serta dengan merujuk kepada kata asal dari korupsi (corrup), maka ia berarti merusak (dalam bentuk kecurangan) atau menyuap. ${ }^{26}$

\footnotetext{
${ }^{25}$ Sayyid Sâbiq, Fiqh al-Sunnah (Mesir: Dâr alThaqâfah al-Islâmiyyah. t.th.), jilid III, hlm. 164.

${ }^{26}$ Lihat tulisan Anis Saidi, Kendala Perkembangan Demokrasi dan Implikasinya Terhadap Penyalahgunaan Kekuasaan (Korupsi), dalam A.S. Burhan dkk, Korupsi Di Negeri Kaum Beragama; Ikhtiah Membangun Fiqh Anti Korupsi (Jakarta: P3M dan Kemitraan Partnership. 2004), hlm. 43.
} 
Perbedaan konsep pada korupsi adalah pada penggunaan ghulûl dan yang lain menggunakan fasâd. Perbedaan ini menuntut peran ulama dan pakar hukum Islam untuk menuntaskan segera, agar mendapatkan dan atau menjadikan kepastian hukum yang harus diterapkan. Meskipun itu, dalam tulisan ini korupsi yang dimaksud adalah lebih dekat kepada fasâd daripada ghulûl, walaupun tidak dipungkiri antara dua konsep ini ada persamaan dalam pengkhianatan kepada Allah dan Rasul saw. serta kejahatan pada negara berupa kejahatan terhadap "basis ekonomi". Hal ini merupakan kewajiban pemerintah untuk segera menuntaskan problematika mewabahnya tindak pidana korupsi tanpa pandang bulu di segala sektor dan level pemerintahan dan masyarakat.

Di antara berbagai bentuk kejahatan tersebut, nampaknya yang paling mirip substansinya dengan korupsi ialah ghulûl ${ }^{27}$ yang diartikan sebagai pengkhianatan terhadap amânah dalam pengelolaan harta rampasan perang dan risywah atau biasa dikenal dengan istilah suap. Dimana seseorang untuk mengerjakan sesuatu pekerjaan telah dibayar, maka apapun selain itu bukan menjadi haknya dan haram mengambilnya. Begitupun jika memanfaatkan harta perusahaan atau negara untuk kepentingan pribadinya, dalam hal ini ia telah mengambil sesuatu yang bukan haknya secara bațil dan

\footnotetext{
${ }^{27}$ Para fuqaha dalam hukum pidana Islam konvensional (fiqh al-jinâyat al-fiqh al-jinâ'i) memasukkan ghulûl dalam kategori tindak pidana (jarîmah) ta'zîr yang besar-kecilnya hukuman ("uqâbah) diserahkan kepada pemerintah dan hakim, hal itu dapat dipahami, mengingat kejahatan ghulûl masih dalam skala kecil yang belum menjadi ancaman berarti. Hanya saja perlu digaris bawahi bahwa hukuman ta'zir kendatipun pada asalnya bertujuan untuk memberi pelajaran (li alta'zib) bentuknya tidak harus selalu berwujud hukuman ringan. Seperti yang ditulis oleh 'Abd al-Qadir Awdah dalam al-Tasyri‘ al-Jinâi al-Islâmî, banyak fuqaha yang membolehkan pidana ta'zîr dalam bentuk hukuman mati, jika kepentingan umun menghendakinya (izâa iqtaḍat al-mashlahat al-'ammah taqrir 'uqûbah al-qatl). Dengan memerhatikan kepentingan umum yang terancam dengan sangat serius oleh kejahatan korupsi saat ini, maka dijatuhkannya hukuman ta'zîr yang paling keras (hukuman mati) atas para koruptor kelas kakap dapat dibenarkan oleh Islam.'Abd. al-Qadir Awdah, alTasyri' al-Jinâ'i al-Islâmî (Bairût: Dâr al-Kitab al- Arabî. 1989), hlm. 1.
}

haram hukumnya. Misalnya, seorang karyawan menerima souvenir sebuah pulpen, parcel di akhir tahun, amplop yang berisi uang atau uang komisi yang biasanya langsung ditransfer, mengambil harta perusahaan/negara, melakukan mark-up suatu transaksi, dan lain-lain. ${ }^{28}$

Kebiasan melakukan tingkah penyalahgunaaan hak atau wewenang tanpa didasari hukum yang tegas, maka orang yang melakukan korupsi tidaklah jera, badan hukum negara di Indonesia yang berpedoman pada garu pancasila belum mampan memberikan hukum yang tegas dan adil bagi bangsa ini. Hukum dunia (samawi) adalah hukum yang tak sempurna, karena Undang-undang khususnya menyangkut tindak pidana korupsi kapan saja bisa dapat dirubah oleh kabinet disebabkan tidak bersifat original. Hukum yang sempurna adalah hukum Allah, yaitu hukum yang tidak dapat ditambah dan dirubah-rubah oleh manusia sebagaimana tercantum dalam al-Quran secara terperinci (tafshilî).

Hukum-hukum yang ditentukan Allah melalui wahyu-Nya dan telah dibukukan menjadi al-Quran adalah untuk dipatuhi bersama sebagai jalan kemaslahatan bagi kehidupan manusia sendiri. Tujuan utama syarî́at Islam (maqâshd al-syarî́ah ${ }^{29}$ ) ialah menjaga dan melindungi kemanusiaan. Perlindungan ini sebagaimana dirumuskan oleh para ulama kedalam lima tujuan (al-maqâshid alkhamsah), yakni perlindungan terhadap agama (hifzh al-dîn), perlindungan terhadap jiwa (hifzh al-nafs), perlindungan terhadap akal (hifzh al-'aql), perlindungan terhadap keturunan (hifzh al-nasl) dan perlindungan terhadap harta (hifzh al-mâl). ${ }^{30}$

\footnotetext{
${ }^{28}$ Lihat Anis Saidi, Kendala Perkembangan Demokrasi dan Implikasinya Terhadap Penyalahgunaan Kekuasaan (Korupsi), dalam A.S. Burhan dkk, Korupsi Di Negeri Kaum Beragama. hlm. 43.

${ }^{29}$ Abû Ishâq al-Syâthibî, Al-Muwâfaqâd fi Ushul alSyarî'ah (Bairût: Dâr al-Kutub al-'Ilmiyyah. t.th.), juz II, hlm. 7. 'Abd. Al-Wahâb al-Khallaf, 'Ilm Ushul al-Fiqh (Cairo: Maktabah Da'wat al-Islâmiyah. t.th.), cet. VIII, hlm. 197.

${ }^{30}$ Abû Hamid Muḥammad Ibn Muḥammad alĢazalî, Al-Musytasfa min 'Ilm al-Ushul (Bairût: Dâr alFikr. t.th.), juz I, hlm. 286. Aḥmad al-Mursi Husain Jawhar, Maqâshid Syari'ah, Penerj. Khikmawati
} 
Tindakan pidana korupsi merupakan perlawanan terhadap tujuan kelima, yaitu hifzh al-mâl. Apabila dalam kepustakaan hukum Islam, contoh populer perbuatan melawan tujuan hifzh al-mâl adalah kejahatan mencuri (al-sarîqah) milik perorangan, maka korupsi adalah kejahatan mencuri harta milik bangsa dan Negara, lebih layak lagi dikategorikan sebagai pelanggaran yang sangat serius terhadap prinsip hifzh al-mâl. Meskipun itu, korupsi bukanlah pencurian biasa yang dampaknya bersifat personal individual, melainkan ia merupakan bentuk pencurian besar yang dampaknya bersifat massal-komunal. Bahkan ketika korupsi sudah merajalela dalam suatu negara, maka negara itu mendekati kepada kebangkrutan dan tak berdaya dalam mensejahterakan kehidupan rakyatnya, tidak mampu menyelamatkan mereka dari ancaman gizi buruk dan busung lapar, maka korupsi lebih jauh dapat dianggap sebagai ancaman bagi tujuan syarî́at dalam melindungi jiwa manusia (hifzh alnafs).

Ketentuan di atas merupakan satu sisi pandangan agar tindak pidana korupsi diterapkan menurut konsep hudûd, sementara korupsi yang terjadi dan berkembang sekarang ini berbeda seperti pada kejahatan mencuri (al-sarîqah). Dalam Islam kejahatan korupsi baik dalam bentuk ghulûl maupun risywah telah dilarang, walaupun tidak terdapat sanksi dalam bentuk nash qath'iî mengenai hukuman bagi koruptor. Hal ini bukan berarti tidak adanya sanksi bagi pelaku korupsi, melainkan dapat dihukum dengan ta'zîr. Fatwa Lembaga Riset Al-Azhar CairoMesir sebagaimana dikutip Muslim Ibrahim menyatakan bahwa korupsi dalam bentuk seperti sekarang ini secara umum tidak termasuk ke dalam hudûd ataupun qishâsh, melainkan sanksi atas kejahatan ta'zîr yang sepenuhnya diserahkan kepada hakim (walî alamri) untuk menentukan sanksi yang sepantasnya, ${ }^{31}$ sesuai dengan tingkat kejahatan-

(Kuwais), Kitab aslinya Maqâshid al-Syarî'ah fî al-Islâm (Jakarta: Amzah. 2009), hlm. xv.

${ }^{31}$ Muslim Ibrahim, Korupsi Dalam Perspektif Figh Islam, dalam Berantas Korupsi: Kajian Ulama Dayah tentang Pandangan Islam terhadap Korupsi (t.t.: Logica. 2009), hlm. 67. Tulisan tersebut merupakan presentasi nya, mulai sanksi minimal sampai sanksi maksimal (mati). ${ }^{32}$ Sementara mengenai pengembalian uang hasil korupsi tidak menggugurkan hukuman, melainkan hak masyarakat, karena tuntutan hukuman merupakan hak Allah swt.

Dalam konteks ajaran Islam yang lebih luas, korupsi merupakan tindakan yang bertentangan dengan prinsip keadilan (al-'adâlah), akuntabilitas (al-amânah), dan tanggung jawab. Korupsi dengan segala dampak negatifnya menimbulkan berbagai distorsi terhadap kehidupan negara dan masyarakat dapat dikategorikan termasuk perbuatan $f a-$ sad, kerusakan di muka bumi, yang juga amat dikutuk Allah swt. Terjadinya kerusakan di muka bumi, pada dasarnya adalah karena perbuatan manusia itu sendiri (baik perorangan maupun kelompok) dengan mengabaikan larangan Allah dan Rasul-Nya, sehingga akibatnya dirasakan oleh manusia secara luas.

Perbedaan mendasar antara persfektif syarî‘at Islam dengan Undang-undang Tindak Pidana Korupsi saat ini, karena menurut fuqaha dan mufassirin ketika menafsirkan QS. Ali Imran:161 dan QS. Al-Mâidah: 33, berikut Hadits-Hadits Nabi saw. memberikan ruang yang amat luas pada para mujtahid. Ketika memberikan ruang bagi para mujtahid, maka terjadi perbedaan pendapat dalam memahami QS. tersebut, beberapa hal dapat dipahami bahwa:

Pertama, korupsi dinilai risywah dan ghulûl. Dalam al-Quran dan hadith tidak dijelaskan hukuman bagi orang yang melakukan penyuapan (risywah), pengkhianatan dengan penggelapan (khiyânat dan ghulûl) ini. Hanya Allah menerangkan dalam QS. Ali 'Imrân: 161 sebagaimana disebutkan di atas. Majelis Ulama Indonesia mengambil ayat dan Hadits yang berkaitan dengan khiyânat ini sebagai landasan hukum korupsi, dan ghulûl diartikan berkhianat atau korupsi. Korupsi dan risywah (sogokan) hanya dinilai haram dan pemerin-

sebagai beberapa catatan dalam diskusi tentang Kajian Ulama Kharismatik mengenai Pandangan Islam Terhadap Korupsi, dilaksanakan oleh MEUMADA di Banda Aceh tanggal 1-3 Oktober 2008.

${ }^{32}$ Wahbah al-Zuhailî, Al-Fiqh al-Islâmi wa Adillatuh (Bairût: Dâr al-Fikr. 1997), juz VII, hlm. 5598. 
tah dan masyarakat berkewajiban memberantasnya (Fatwa MUI, 2003: 275) tanpa menyebutkan hukum pidananya. Demikian pula Hadits-Hadits yang berkaitan dengan khiyânat atau ghulûl ini menjadi landasan syar'î yang dikemukakan MUI, seperti Hadits yang menerangkan bahwa pegawainya yang diutus ke daerah untuk mengambil sadaqah, lalu mereka memilah-milah mana buat dirinya mana buat Nabi Saw. (Pemerintah). Menurut Abû Hurairah suatu waktu Rasulullah berpidato:

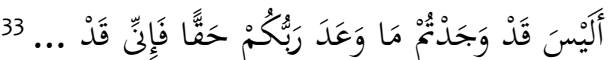

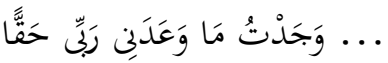

...Sungguh aku tidak akan menemukan salah seorang di antara kalian akan kembali kepada Tuhanmu secara benar, akan tetapi sebaliknya sungguh saya menemukan siapa yang kembali kepada Tuhannya secara benar .... (HR. Muslim).

Nabi Saw. pada Hadits ini tidak menyebutkan hukuman pidana yang melakukan penggelapan, sogokan atau korupsi, tetapi hanya menceritakan hukuman di akhirat belaka. Agaknya, MUI menyerahkan hukumannya kepada pemerintah (ûli al-amri), yaitu ta'zîr yang berat dan tidaknya hukuman berdasarkan ijtihad, yaitu peraturan perundang-Undangan. Di sini memerlukan ketetapan ijtihad para ulama yang lebih menukik pada penegakan keadilan, yaitu kekayaan apapun milik negara yang diperuntukkan untuk kepentingan rakyat harus dipelihara dengan prinsip hifzh al-mâl harus ditegakkan, maka hukuman yang keras harus ditegakkan agar menjerakan.

Kedua, mengartikan korupsi dengan ifsâd, maka hukumannya akan dianalogikan kepada hirâbah. Bila analogi (qiyas) ini diterima, maka acuan yang digunakan sebagai landasan hukum adalah QS. Al-Mâidah: 33 yang berbunyi:

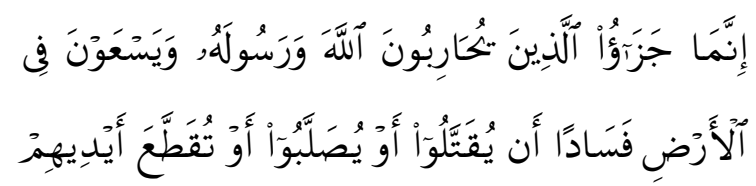

${ }^{33}$ Muslim, Shahîh Muslim, No. 7403, juz VIII, hlm.

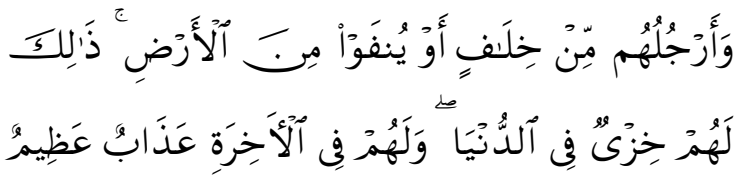

Sesungguhnya pembalasan terhadap orangorang yang memerangi Allah dan Rasul-Nya dan membuat kerusakan di muka bumi, hanyalah mereka dibunuh atau disalib, atau dipotong tangan dan kaki mereka dengan bertimbal balik, atau dibuang dari negeri (tempat kediamannya). yang demikian itu (sebagai) suatu penghinaan untuk mereka didunia, dan di akhirat mereka beroleh siksaan yang besar. (QS. Al-Mâidah: 33)

Pada ayat ini ada beberapa alternatif menyangkut hukuman, yaitu dibunuh, disalib, potong tangan dan kakinya secara silang, dan dibuang. Para fuqaha menyebutkan bahwa saat sekarang dibuang diartikan dengan dipenjara. Namun apabila melihat kepada terjemah bahasa korupsi adalah fasad atau ifsâd, maka koruptor adalah sama dengan hirabah dan menyebarkan kerusakkan di muka bumi, yaitu merampok kekayaan publik yang mengakibatkan rusaknya tatanan basis perekonomian. Oleh karena itu, hukumannya adalah salah satu di antara empat alternatif di atas, akan tetapi hukuman yang menjerakan adalah dengan dihukum mati. Menurut fuqaha, hukuman mati jika perampok itu membunuh saja, namun apabila disertai perampokan harus disalib. Jika merampok tanpa pembunuhan dipotong tangannya dan bila hanya mengganggu masyarakat, tanpa mengganggu jiwa dan harta harus dibuang ke tempat lain (dipenjara di tempat yang jauh).

Dalam Undang-undang Pemberantasan Tindak Pidana Korupsi Tahun 2002, hukuman mati merupakan hukuman maksimal dan minimalnya adalah hukuman penjara tiga tahun. Undang-undang tersebut dalam pemahaman penulis, meskipun belum memenuhi keseluruhan implimentasinya, setidaknya minimal senafas dengan QS. Al-Mâidah: 33. Pada tahun 2003 koruptor satu milyar ke atas disidik oleh KPK dan tentu saja dengan 163. 
kewajiban mengembalikan uang yang dikorup, mengganti kerugian negara, dan wajib membayar denda. Seperti juga ayat di atas, mufassir mewajibkan mengembalikan uang yang diambil karena hubungannya dengan huqûq al-insân (hak-hak manusia).

Hukum yang keras seperti itu karena mereka telah melakukan kejahatan dua kali, yaitu berkhianat pada Allah dan Rasul serta berkhianat pada umat dan masyarakat umumnya. Berkaitan itu, persoalan di Indonesia tampaknya bukan pada tataran hukum, tetapi pada tataran implementasi hukum itu sendiri, sehingga korupsi tidak bisa dihilangkan atau minimal ditekan. Karena ilai-nilai universal al-Quran dan sunnah memang memberikan perspektif preventif terhadap pelaku kejahatan, intinya ialah sebagai upaya pemeliharaan lima tujuan (al-maqâshid alkhamsah). Islam dipahami lebih bersifat preventif dalam menentukan hukuman-hukuman bagi pelaku kejahatan baik pada penggunaan ghulûl atau fasâd, sehingga masyarakat pada periode pertama (Nabi Saw.) dan periode shahabat kurang berani melakukan perbuatan itu. Namun perkembangan selanjutnya ketakutan melakukan perbuatan itu agak sedikit berubah dan membutuhkan pemberantasan secara tegas, hingga pada akhirnya harus sampai pada titik balik bahwa koruptor harus bisa dijerat dengan hukuman yang berat supaya merasa jera apabila melakukan tindak pidana korupsi.

Dalam pidana Islam sanksi bagi perbuatan bagi perbuatan korupsi dapat diterapkan bervariasi sesuai dengan tingkat kejahatannya. Mulai dari sanksi material, penjara, pemecatan jabatan, cambuk, pembekuan hakhak tertentu sampai hukuman mati. Bervariasinya sanksi tersebut, karena tidak adanya nash qath'i yang berkaitan dengan tindak kejahatan yang satu ini. Artinya sanksi syari'at yang mengatur hal ini bukanlah merupakan paket jadi dari Allah swt. yang siap pakai. Melainkan sanksi dalam perkara ini termasuk sanksi ta'zîr, yaitu sanksi yang ketiga setelah sanksi hudûd dan qishas diyât dalam hukum Islam. Seorang hakim (imam/pemimpin) diberi otoritas atau kewenangan penuh untuk memilih sanksi yang tentunya berdasarkan ketentuan syarî‘at, yaitu bentuk sanksi tertentu yang efektif dan sesuai dengan kondisi ruang dan waktu, di mana kejahatan tersebut dilakukan.

\section{E. Penutup}

Berdasarkan uraian di atas, maka dapat disimpulkan bahwa persoalan penegakan hukum terhadap tindak pidana korupsi memerlukan komitmen dari para pemimpin negara, agar dapat melahirkan keputusan; memilih tenaga yang kompeten untuk melakukan tugas pemberantasan; membuat peraturan hukum yang kondusif untuk pemberantasan (amandemen Undang-undang anti korupsi seringkali dilakukan agar dapat menutup celah kekurangan); perlu adanya kompensasi yang memadai sehingga mendapat aparatur yang kompeten dan dapat bekerja secara optimal.

Dalam pandangan penulis, sanksi yang akan diterapkan kepada pelaku tindak pidana korupsi melalui konsep ta'zîr dapat dikategorikan kepada tiga tingkatan, yaitu: Pertama, sanksi berat (mughalladzah), seperti hukuman mati dan penyaliban, yaitu penerapan hukuman yang dilakukan bagi pelaku tindak pidana korupsi di atas Rp. 100.000.000,- (seratus juta rupiah); Kedua, sanksi sedang (mutawâsithah), seperti hukuman dera, penjara, pembuangan, penyitaan harta, pencopotan jabatan, tidak dapat menjasi saksi, penyebarluaskan berita tindak pidana yang bersangkutan, dan denda. Sanksi ini diterapkan terhadap pelaku tindak pidana korupsi di atas Rp. 5.000.000,- (lima juta rupiah) sampai Rp. 100.000.000,- (seratus juta rupiah); dan Ketiga, sanksi ringan (mukhaffafah) seperti hukuman peringatan, ancaman, dan hardikan. Hukuman ini berlaku bagi pelaku korupsi yang nominalnya sangat minim, yaitu antara nol rupiah sampai Rp. 5.000.000,- (lima juta rupiah).

Mengingat tindak pidana korupsi terjadi dalam berbagai multidemensi, maka konsep hukum materil dan formal Islam yang ada untuk mencegah dan memberantas terjadinya korupsi, sangatlah layak untuk dipertimbangkan dan menjadi kontribusi melalui peraturan perundangan TIPIKOR di Indonesia. Terutama pasal-pasal yang telah disebutkan di atas sebagai dasar dan menjadi 
amandemen UU Tindak Pidana Korupsi yang ada (UU Nomor 20 Tahun 2001).

\section{Daftar Pustaka}

Mujib, Abdul, LM. ed. 1994.Kamus Istilah Fiqih. Jakarta : Pustaka Firdaus.

Gazâlî, Abû Hamîd Muhammad Ibn Muhammad, al-. t.th. Al-Musytasfâ min 'Ilm alUshûl. Bairut: Dâr al-Fikr.

Abû Zahrah, Muhammad. t.th. Târîkh alMadhâhib al-Islâmiyyah. Mesir: Dâr alFikr al-'Arabî.

Khudarî Bayk, Muhammad, al-. 1988. Ushûl al-Fiqh. Cairo: Dâr al-Fikr al-'Arabî.

Jawhar, Ahmad Mursi Husayn, al-. 2009. Maqâshid Syarî‘ah, Penerj. Khikmawati (Kuwais), Kitab aslinya Maqâshid alsyarî‘ah fî al-Islâm. Jakarta: Amzah.

Awdah, 'Abdul Qadir, al-. 1989. al-Tasyri'alJinâi al-Islâmî. Bairût: Dâral-Kitabal- Arabî.

Khallaf, 'Abdul Al-Wahhâb, al-. t.th. 'Ilm Ushûl al-Fiqh. Cairo: Maktabah Da'wat alIslâmiyyah.

Zuhailî, Wahbah, al-. 1997. Al-Fiqh al-Islâmi wa Adillatuh. Bayrut: Dâr al-Fikr.

Anonimios, Syariat Islam dalam pemberantasan Korupsi, lihat di http://www.slideshare.net/alphaniphajar/13-syariatislam-dalam-pemberantasan-korupsi di akses pada Tanggal 02 Januari 2013

Azadia, Zahra.t.th. Korupsi dalam Islam. Lihat di http://www.academia.edu/4918447/HUKUM_KORUPSI_MENURUT_ISLAM diakses pada tangga 31 Janauari 2013

Baltaji, Muhammad. 2005. Metodologi ljtihad Umar bin Khathab, Penerj. Masturi Irham, Judul Asli: Manhaj 'Umar bin alKhatțâb fi al-Tasyrî'Dîrâsah Mastaw'abah li Fiqhi 'Umar wa Tanzîmâtuh. Jakarta: Khalifa.

Burhan, A.S.dkk. 2004. Korupsi Di NegeriKaum Beragama; Ikhtiah Membangun Fiqh Anti Korupsi. Jakarta: P3M dan Kemitraan Partnership.

Syarwanî, 'Abdul Hamîd, al-. t.th. Hawâsyi alSyarwanî. Bairūt: Dâr al-Fikr. t.th.
Hakim, Abdul Hamid. 1939. Al-Bayân. Bukittinggi: Maktabah al-Ma'arif.

Ibrahim, Muslim. 2009. Korupsi Dalam Perspektif Fiqh Islam, dalam Berantas Korupsi: Kajian Ulama Dayah tentang Pandangan Islam terhadap Korupsi. t.t.: Logica.

Syâthibî, Abû Ishâq, al-. t.th. Al-Muwâfaqâd fi Ushûl al-Syarî'ah. Bairūt: Dâr al-Kutub al'Ilmiyyah.

Klitgaard, Robert. 2001. Membasmi Korupsi. Jakarta: Yayasan Obor Indonesia.

Nata, Abuddin. 1994. Al-Quran dan Al-Hadits. Jakarta : Raja Grafindo Persada.

Nurdin, Nazar. t.th. Fiqih Anti Korupsi. Lihat di http://www.islamlib.com/?site=1\&aid$=1785 \&$ cat $=$ content $\&$ cid $=24 \&$ title $=$ fikih anti-korupsi di akses pada 27 April 2013

Pope, Jeremy. 2003. Strategi Memberantas Korupsi; Elemen Sistem Integrasi Nasional. Jakarta: Yayasan Obor Indonesia.

R, Atmasasmita. 2004. Sekitar Masalah Korupsi, Aspek Nasional dan Aspek Internasional. Bandung: Maju Mundur.

Rais, Isnawati. t.th. Korupsi dalam Pandangan Islam. Lihat di http://tabligh.or.id/2013/korupsi-dalam-pandangan-islam/ diakses pada 03 April 2013

Praja, Juhaya S.. 2009. Teori-Teori Hukum: Suatu Telaah Perbandingan dengan Pendekatan Filsafat. Bandung: Pascasarjana Universitas Islam Negeri.

Sâbiq, Sayyid. t.th.Fiqh al-Sunnah. Mesir: Dâr al-Thaqâfah al-Islâmiyyah.

Madkûr, Muhammad Salâm. t.th. Al-Madkhal li al-Figh al-Islâmî. Bairūt: Dâr al-Fikr.

Supangat. t.th. Sanksi Hukum Terhadap TindakPidana KorupsiBagi Penyelenggara Negara Dalam Perspektif Hukum Islam, lihat di http://supangat.blog.walisongo.ac.id/2013/12/07/sanksi-pidana-koruptordalam-prespektif-hukum-islam/ di akses pada 30 Mei 2013

Syahrastânî, Muhammad Abû Bakar, al-. t.th. Al-Milal wa al-Nihâl. Bairūt: Dâr al-Fikr.

Taimiyyah, Ibn. 1980. Kitab Iqâmah al-Dalîl 'ala Ibtal al-Tahlîl dalam Majmu'ah Fatawa Ibn Taimiyyah. Bairūt : Dâr al-Fikr.

Taqwaddin, 2009. Esensi Hukum Rajam. Lhokseumawe: Serambi. 
Wahidin, 2006. Metodologi Pemikiran ljtihad Fiqih Antara Pendekatan Ta'abbudi dan Ta'aqquli. Jurnal Hukum Islam.
Warson Munawwir, Ahmad. 1984. Kamus alMunawwir. Yogyakarta: Yayasan AlMunawwir. 